\title{
Corruption: The hidden perpetrator of under-development and vul- nerability to natural hazards and disasters
}

\author{
James Lewis \\ Datum International
}

The Pat Reid Lecture 2010

African Centre for Disaster Studies

North West University, Potchefstroom, South Africa

September 2010

"Formerly LeverhulmeSenior Research Fellow and co-founder of the Disaster Research Unit, University of Bradford (1973-77), James Lewis relocated to the University of Bath and became Visiting Fellow at the Centre for Development Studies. Datum International was created in 1980 for consultancy to the United Nations (UNCTAD, UNEP, UNESCO, UN Habitat \& WHO), the Commonwealth Secretariat/Commonwealth Fund for Technical Cooperation, and the European Commission. James Lewis is author of Development in Disaster-prone Places: Studies of Vulnerability (1999: IT/ Practical Action, London) and of numerous chapters and papers on vulnerability to natural hazards, corruption, island vulnerability, climate change, and interconnections with socio-economic capacity, development and disaster risk reduction. As a commissioned author to Transparency International Berlin, he has contributed to Global Corruption Reports of 2005, Corruption in Construction, and 2011, Corruption and Climate Change. Trained and practiced as an architect and member of the Royal Institute of British Architects (RIBA), James Lewis has been involved in applications, implications, management and inspection of construction, destruction and reconstruction in Algeria, Bangladesh, the Caribbean, China (Hong Kong), the South Pacific, the United Kingdom and the USA. www.datum-international.eu"

May I first of all say that it is my great privilege to be at North-West University Potchefstroom, and with the African Centre for Disaster Studies who I thank most sincerely for their invitation to deliver this Pat Reid Lecture 2010.

I have known of South Africa since my boyhood but, though my work has taken me to other parts of the Continent, this is the first time I have had the opportunity to visit.

My lecture is based upon a fully referenced paper but it is not an academic paper that contains evidence from which it draws conclusions. It's in the nature of corruption that there is little evidence and there are no text-books, no journals devoted to its practise and no guidelines. Instead there is observation, financial calculation, investigative journalism, and an increasing number of legal investigations and trials of its perpetrators to draw upon. When evidence is in short supply, therefore, it becomes necessary to rely upon inquiring minds. 
Corruption is the abuse of entrusted power for private gain. It hurts everyone whose life, livelihood or happiness depends on the integrity of people in a position of authority (Transparency International, 2010).

Corruption, in some degree pervades all countries, so I want to say at the outset, that my being in South Africa is not the reason for the selection of my topic. That South Africa may have its problems (Smith, 2010) does not make it internationally a special case. My purpose is to speak generally about the link that indubitably there is between corruption, underdevelopment and disasters, and to describe some of the longer-term consequences of corrupt practises.

Transparency International in Berlin, with more than 90 locally established national chapters, annually tabulates a scale of corruption as internally perceived in 180 counties and known as the Corruption Perceptions Index (cf. Transparency International, 2009). Countries high on the scale are perceived to have less corruption than those lower on the scale. The offering of a bribe is regarded as being as wrong as is the taking of bribes.

I appreciate that the topic of corruption is not an attractive one. As a conversation stopper amongst the "chattering classes" it is usually passed off as "hasn't there always been corruption?" or, "isn't that the usual way of doing things there?" or, "isn't that the oil that makes society work there?" - always with the idea that corruption is something that happens elsewhere than in one's own country. We all prefer not to discuss those things with which we feel uncomfortable but, I have come to realise, corruption is so significant that it can no longer be shrugged off and that, moreover, the legacies of corrupt practises are consequences that must be exposed and understood for the damage they do to all of us - and in so much of what we do.

Having faced the tentacles of corruption in some of my earlier working environments, I have researched and written about corruption for a number of years (cf. Lewis, 2008a). I began by exploring corruption in construction and how it can be a cause of the collapse of buildings in earthquakes (Lewis, 2005). Not only does corrupt practice pervert the execution of construction but, by the siphoning of finance at its source, it denies the opportunity to build or, at most, reduces the amount and the quality, and increases the cost, of new building and infrastructure.

Construction bad practice, a result of attempted reductions in overheads exacerbated by the payment of dues and backhanders, may not be revealed except by an earthquake many years after builders and original owners have moved on. And, as the maxim goes, earthquakes don't kill anyone but collapsing buildings do. Not only are people killed and injured in very large numbers but, in one form or another, there is the cost to society of that loss and of the cost of reconstruction. But although the construction industry world-wide is recognised as one of the most corrupt, corruption pervades more than that one sector.

Perhaps as an indication of corruption now being taken more seriously, investigations into corruption have increased in recent years. As well as those undertaken internationally by Transparency International, there are investigations by the World Bank, the Organisation for Economic Co-operation and Development (OECD) and by private consultancies, into the economic effects of corruption. Work on corruption in some African countries is being 
undertaken in Construction Management at the Nelson Mandela Metropolitan University in Port Elizabeth (Shakantu, 2003).

The link between corruption and disasters, however, is more pervasively invidious, even, than its effect in earthquake damage. The audacity of corruption and its massive impact, combine in their enormity to the extent that, in some of the poorest countries, it is difficult not to conclude that corruption should be investigated as a significant cause of regional and sometimes even of national poverty.

It is not so much the hierarchical greed with which corruption is riddled, nor even its spread, but its scale and the consequences of that scale in relation to under-development, vulnerability and disasters that I have become concerned about.

The few examples that follow are in alphabetical order of country, so a general reference to Africa has to come first:

\section{Africa}

In some African countries and before it could be spent on infrastructure and general construction, millions of dollars of international aid have been sent to private external bank accounts, often those in the countries of the origin of the aid. To quote an American source: “...we have $\$ 50,100$ billion of aid flowing into poor countries, and $\$ 500,800$ billion of dirty money flowing out. In other words, for every dollar Western governments have been handing out across the top of the table, crooked Western banks, businesses and middlemen of various descriptions have been taking back up to ten dollars of illicit proceeds under the table" (Baker et al., 2008).

\section{China}

In China, the government has more than 1,200 laws, rules and directives against corruption but implementation is ineffective. With only a 3 percent likelihood of a corrupt official being sent to jail, corruption is a low-risk high-return activity. Even low-level officials have the opportunity to amass an illicit fortune of tens of millions of yuan.

In 2007, for example, the year before the Richter 7.9 Sichuan earthquake, the CCP secretary in Janwei county of Sichuan province was reported as having acquired 34 million yuan (US\$ 5 million / ZAR 36 million). An anti-corruption chief of another province collected bribes worth more than 30 million yuan (US\$ 4.4 million / ZAR 32 million). Despite the laws, rules and directives against it, corruption in China is concentrated in those sectors with extensive state involvement, such as infrastructure projects and government procurement (Pei, 2007).

Strong public allegations were made after the Sichuan earthquake, when so many schools were destroyed, some buildings collapsing adjacent to others that did not. Seven thousand school classrooms were reported as having been destroyed. The inward total collapse of Juyuan Middle School itself caused the deaths of 900 children, triggering vociferous local protests: "The local officials get money from above and then they take it for themselves". The school has become "a bleak symbol of the deadly mix of natural destructive power and slipshod building...". The Chinese government have instituted an inquiry into why so many schools collapsed but the results have not yet been made accessible. 
The costs of corruption in China have been estimated as 10 per cent of spending during a ten year period ending in 2005. Minxin Pei, a Chinese-American writer has claimed that: "To estimate roughly the direct costs of corruption, we can suppose that 10 per cent of government spending, contracts, and transactions is used as kickbacks and bribes or is simply stolen" (cf. Pei, 2007).

"In the heart of the disaster zone", the Bechuan county Liu Han Hope Elementary school and all of its 483 children survived, its community expressing gratitude for "the effort the company put into building the schools in the first place". Its project manager recalls "his bosses had stressed the importance of safety" but also he recalled "the battles that had been involved... to force the builders to replace substandard cement (ie: concrete) and with officials who had intercepted part of the funding" (Branigan, 2008).

Design and specification to statutory regulations and codes is compromised by depletion of funds for contract payments. Institutionalised depletion of funding for new schools would explain the high incidence of school building failure. On site, Chinese builders are said to often use a series of local subcontractors, a practice that complicates working procedures, obscures shortcomings and substandard substitutions, and by which costs are increased "as each contractor takes his share of the project budget".

In 2009, China was 79th on the Transparency International corruption index of 180 countries.

\section{Italy}

In Italy, according to Alexander (2005), all of the four mafias are based in the area known as the Mezzogiorno, in the south, where incomes and standards of living are generally lower, illiteracy higher, and earthquakes are larger and more numerous than in other parts of the country.

In 1946, following the end of World War 2, large-scale land reforms were instituted much later than in the prosperous north and a fund was initiated by central government to stimulate social and economic development for the South. From these and other development initiatives, billions of dollars for development support from the Italian and United States governments, the World Bank, and the European Commission "disappeared". It has become impossible to separate the mafia from political corruption in this region of Italy.

The extent and enormous scale throughout Italy, of criminal fraud and corruption in the management of public works construction is revealed as intended and premeditated. In 2005 public works infrastructure was declining in spite of declared national policy to achieve the contrary. This comparison of built infrastructure values against government public works expenditure per region, shows southern Italy as having received more public works finance over the years, even though it has less infrastructure, with the most corrupt region spending four times more per infrastructure unit than the least corrupt region. The difference is interpreted as a measure of corruption: the regions that did not get what was paid for are those where politicians and bureaucrats were siphoning-off public money before and during the construction process. 
In contexts of this kind, where endemic criminal fraud and embezzlement have become entrenched, almost traditional and in some areas, a tourist attraction, it would be difficult for any relatively small-scale building contractor to behave honestly - if, after paying his backhanders, such a contractor could afford to do so.

Italy is at 63 on the 2009 Transparency International PC Index of 180 countries, equal with Saudi Arabia.

In the United Kingdom - you may have been wondering - BAE Systems, formerly British Aerospace, admitted guilt in February 2010 to false accounting and making misleading statements, but not of alleged bribery. They were fined $£ 300$ million (ZAR 3,423 million). Payments had been made to intermediaries for an already rich Saudi prince of "secret commissions" totalling $£ 10$ million and US\$9million in connection with a contract worth $£ 43$ billion (ZAR 491 billion) for the provision to Saudi Arabia of al-Yamamah fighter planes. It was alleged that similar payments had been made to Tanzania, South Africa, the Czech Republic, Hungary and Romania.

In 2009, before this case came to court, the United Kingdom was at 17 on the Transparency International PC Index, equal with Japan.

Other countries provide other examples: for example, large proportions of post-conflict USAfunded reconstruction budgets in Iraq were made to entirely disappear due to corruption (Glanz, 2006); corrupt construction practice was identified in Turkey as the reason for poor quality building stock and the collapse in the 1999 earthquakes of "mid-rise apartment blocks constructed of reinforced concrete". State authorities allocated blame solely to a failed system of building control, allegedly to deflect blame away from facilitation and condonation of corrupt practices within their own management systems.

Across earthquake-prone Japan in 2005, 78 buildings including 36 hotels were declared unsafe. Falsified earthquake resistance data had been submitted by their architect under pressure from his client during pre-construction stages. Apartment block residents were ordered to leave and hotels were forced to close to await demolition. In some cases, it was reported, steel structural members were one quarter of their required size.

Most of my examples are taken from the construction industry, I think not only because of my own background and experience but because physical examples are more visible. These physical examples can be regarded as epitomising corrupt practise in all sectors of activity.

Contracts and permissions procured by bribery lead to backhanders down the line to such a degree that contractors and subcontractors are obliged to make "substantial economies", for example, by the omission of cement and steel from reinforced concrete. In much the same way, bribery everywhere filters money away that could and should be spent to the benefit of community, society or country, that is, building occupants, people at large, taxpayers and governments. 
Payments of sometimes massive bribes are set against declared company profits, the basis upon which tax payments usually are calculated. Money which could have been spent for the benefit of society at large is therefore depleted on such a scale that health care, housing and education, social stability and natural environments are threatened or rendered inadequate and degraded.

In large scale public works, such as in the example from Italy, in which collusion between levels of administration, elected officials, bureaucrats and private contractors is endemic, it has to be obvious that for such abuse of public office for personal gain to persist country-wide, elected officials are necessarily and regularly involved (Golden \& Picci, 2005).

According to Golden and Picci (2005) extensive and persistent corruption in any sector can't be regarded as a phenomenon isolated from its broader political context; a political environment of corruption involves a non-benevolent principal rather than being a benign bureaucratic or institutional slippage from a benevolent one.

As in construction, whether localised, national or international, frequent, consistent, informed and independent inspection to ensure accurate execution is required. The same requirement for a higher degree of transparent audit applies to all government and commercial accounting procedures. Inspection needs to be inclusive of contractual authority to facilitate the stopping of work or the cessation of trading, the in-depth examination of suspect work, and the removal of work or materials shown to be inadequate. These are expensive procedures and awareness of their potential implementation will be a first measure towards compliance (Lewis, 2010b).

The very availability of land upon which to build, and permissions or licences to build upon it, is achieved by bribes and backhanders; land more likely to be exposed to flooding or slippage, or to be not firm - in other words, land which would not normally have qualified for permission to build.

The places in which people are obliged to build, or where buildings are built which people then occupy, have as much to do with vulnerability to natural hazards as does building construction and occupation; vulnerability being exacerbated for millions of people for whom there are no options about the places they inhabit, who are obliged to respond to policies and activities in the control of others, or to corrupt external pressures in the interests of others.

Such perpetrations as these, and others like them, are serious contributors to underdevelopment.

\section{Under-development}

We need to look at the concept of under-development so as to explore connections between corruption and development. The following extracts, as relevant today as when they were written, are taken from Henry Bernstein's book of 1976, a reflection of the intensity of application to the subject of that time. He and Celso Furtado, a writer from Brazil and one of his contributors, wrote:

“...the movement for development embodies a value judgement with which few would disagree: the desirability of overcoming malnutrition, poverty and disease which are the most immediate and widespread aspects of human suffering. In positive terms some advocate a commitment to 
development that transcends the limiting terms of economic growth to embrace such features of social justice as equality of opportunity, full employment, generally available social services, equitable distribution of income and basic political freedoms. In these terms a broad consencus may be discernable, but such an agreement on desired ends does not necessarily take us far in understanding the realities of the contemporary world." Surely a prescient observation?

"The result...[has been] almost always to create hybrid (administrative) structures, part tending to behave as a capitalistic system, part perpetuating the features of the previously existing system. The phenomenon of underdevelopment today is precisely a matter of this type of dualistic economy" (Furtado, 1976).

"The practical result of this...is that the occupational structure of the country changes only slowly. The part of the population affected by development remains minor, and there is a very slow decline in the relative importance of the sector whose main activity is production for subsistence. This explains why an economy in which industrial production has already achieved a high degree of diversification...may present a rather pre-capitalistic occupational structure and have a large portion of its population cut off from the benefits of development" (Furtado, 1976).

Underdevelopment then, is the presence in any country of some areas of a consistency less than that recognised as the prevailing norm. The "desirability of overcoming malnutrition, poverty and disease", of "social justice and equality of opportunity" and "equitable distribution of income" may progress nationally but the poor remain poor and "cut off from the benefits of development".

By development funds being siphoned away for personal gain, corruption depletes or impedes the "desirability of overcoming malnutrition, poverty and disease", so that although the norm of national development may rise, underdevelopment persists. "Social justice and equality of opportunity" are denied and defiled, as is "equitable distribution of income". Corruption confirms an inequitability that ensures that the poor remain "cut off from the benefits of development" and consequently, impoverishment and the vulnerability it feeds are exacerbated. Everywhere and in any country, the poor and marginal invariably are the most vulnerable.

Further than this, corruption achieves its own "development", skewed and designed for further personal gain, that is not only not in the public interest but which is contrary to it. Corruption twists the flow of development to its own ends and to its own advantage. The housing development by Italy's prime minister, following the 2009 L'Aquila earthquake, is a topical example (Poirier, 2010).

\section{Vulnerability}

It becomes possible, therefore, to envisage how corruption contributes to vulnerability to natural hazards (Lewis, 2010c). According to Lewis and Kelman (2010) vulnerability results from applied processes by which accrue the susceptibilities of people, infrastructure, communities, and environments. Due to poverty, oppression, and lack of choice, people become obliged, or are forced, to lead their lives in hazard-prone places, or in places that become hazard-prone by 
change over time. "Vulnerability is a morphological, cumulative and collective condition. It is not one which results only from each isolated damaging possibility as it becomes apparent or manifest" (Lewis, 1999:31).

Vulnerability is therefore dynamic, not static and it has frequently been demonstrated that some, perhaps the majority, of vulnerabilities result, or evolve from, the actions of others, taken usually in their self-interest, either in present time or in the past (cf. Oliver-Smith, 1986; Jeffery, 1982; Hewitt, 2007; Lewis, 2007; Wisner et al., 2004).

Current vulnerabilities have a past in which they may have accrued, or have been caused or exacerbated, by the actions of others - others, who may be remote and beyond the influence or control of people and places rendered vulnerable.

Domestic vulnerabilities, brought about, for example, by a lack of awareness or by inappropriate decision making, can be caused by limitations of livelihood options, by restrictions upon land use, by exploitation of people and resources, or by resulting poverty, lack of control and powerlessness.

Other vulnerabilities are caused by political and economic pressures; partitioning of communities for land acquisition; removal of occupants from traditional resources and, by all of these, the resulting occupation of marginal land inevitably more exposed to environmental change and its hazards. Consequently no longer able to grow food crops or to maintain livestock in sufficient quantities, or effectively access employment, resources or services, communities are made to become disparate, exploited, disadvantaged, marginalised - and increasingly vulnerable.

Marginalisation, as an end product of external control, appropriation, disadvantage and inequality (Dorling, 2010), is a process not unique to rural areas. It exists in urban and periurban areas of formal and informal settlements (Kreimer et al., 2003) where, due to similarly invidious processes, high land and property values are made an excuse for evictions of the many in favour of profit for the few and a cause of vulnerability for destabilised occupants.

Corruption is a serious driver of social and ecological imbalance, and a contributor to vulnerability of industry, commerce, construction, health and agriculture. By aggressive siphoning of funds at source, and by exploitation, acquisition, insider dealing, cartels, price fixing and sub-standard construction (cf. Lewis, 2003; Lewis, 2008a; Lewis, 2008b; Baker et al., 2008; Salih, 2010), access is denied to millions of their share of the benefits of development.

Clearly, vulnerability not only has to do with poverty, but with the causative actions and inactions that create poverty.

\section{Disasters}

Not all failed development, and not all failures of construction, are caused by corruption but, nonetheless, these descriptions of how conditions of vulnerabilities to natural hazards accrue, and of some of the influences that contribute to that process, indicate that disasters don't commence with the drought, the storm, or the flood, the earthquake or the fire, or the food scarcity. The contexts for disasters commence before, sometimes a very long time before, 
the occurrence of the event that triggers what we have misleadingly come to call a "natural disaster". Corruption is an insidious contributor to that process.

In Pakistan this year, for example, millions of people have been affected by torrential monsoon rains and serious fast-flowing floods. In August, 54 entire villages had been washed away entirely, 1,600 people had died, 2 million made homeless (Shah, 2010) and dissent was leading to political instability (Ellick, 2010).

It was reported by Shamsie (2010) that the "timber mafia", "one of the most powerful and ruthless organisations within Pakistan" had long been engaged in illegal logging...worth billions of rupees each year". De-forested regions anywhere are more susceptible to flooding, landslides and soil erosion but, in Pakistan, illegally felled trees, hidden in ravines, were dislodged by floodwaters and, by their impact, destroyed bridges essential for access to flooded areas. Dams and retaining walls intended for flood control possibly were weakened.

Pakistan is $139^{\text {th }}$ on Transparency International's PC Index of 180 countries.

\section{Climate change}

As the consequences of climate change world-wide are making themselves apparent, adaptation, corruption and people's vulnerability are interlinked. Corruption acts as an engine of poverty and vulnerability, creating weaknesses that are exacerbated by changes of climate. Climate extremes will especially affect poorer countries, in many of which endemic corruption accompanies weak governance and adaptation funding is exposed to corrupt depletion. Impoverished communities already suffer a disproportionate share of losses in extreme weather events and are then rendered even more vulnerable to subsequent extremes of climate and corruption.

As massive amounts of money are directed towards adaptation to the effects of climate change, issues of corrupt practise must be raised so that governance can itself adapt to the rigorous and disciplined management that is required to ensure that funds are used in their entirety for the purpose for which they have been raised and to the benefit of us all (Lewis, 2010a).

I hope I have shown something of how the disasters that ensue from the hazards with which we are all afflicted, are not "natural" at all but are brought about by the actions and inactions of mankind. But that we, as humans, have the capacity to perpetrate these and other causes of disasters, is indication that we also have the capacity to prevent or to ameliorate them. If, for example, we undertook to examine in-depth the contexts in which disasters occur, whether they be triggered by epidemic, drought, food insecurity, flood, fire or storm, and inclusive of longer-term as well as recent pasts, we would be better equipped to manage our development, not only to improve current conditions where improvement is required, but to ensure that what we do now will not exacerbate risk for the future.

As I have written in Lewis (1999), it is high time that development itself came to be designed 
with people's survival as its objective because, without survival, recovery cannot succeed. To this purpose, one of the first things to be done is to eradicate the pernicious perpetrations of corruption that serve to make matters worse - not better.

Responding to Professor Frik van Niekerk's (Institutional Director: Research and Innovation: NWU) question "What about South Africa", James Lewis referred to reporting in a current issue of the Mail \& Guardian of an investigation into the provision by the South African Police Service of three police stations (cf. Donnelly, 2010).

Inanda Police Station had taken six years to build during which costs soared from a budgeted R15.9 million to an actual cost of R42 million; Ezakheni Police Station had been estimated to cost R10.6 million but grew to an actual cost of R23.9 million and construction of Hebron Police Station, begun in June 2006, was continuing (at September 2010) with a budgeted cost of R14.7 million and a current cost of R18.6 million and rising. The average cost of consultants' fees was reported as $18 \%$ of a project's budget, "but in some projects it was as high as $25 \%$ ".

Mr Lewis commented that reportedly high consultants' fees would usually imply appropriately rigorous financial management and control. Contracts for buildings under construction normally allow for "contingencies" to cover unexpected costs, especially below ground level involving foundations but perhaps also involving fluctuations in market prices or agreed substitutions of materials or fixtures.

Such contingencies, however, would not normally be expected to increase contract costs by more than 10-15 per cent, whereas the cost of two completed police stations had reportedly increased by 264 and 225.5 per cent and that of the then incomplete police station by 126.5 per cent. Close examination was required into the reasons for extended completion times which suggested the possibility of contractor and consultant complicity, perhaps under external pressure.

For these three police stations, including one not yet complete at the time of reporting, R84.5 million of public money had been over-spent on three contracts budgeted at a total of R41.2 million - an overall expenditure of more than twice the budgeted cost. Six police stations, or their equivalent, could have been provided for the ultimate actual cost of three.

\section{References and notes}

ALEXANDER, D. 2005. The Italian mafia's legacy of high-rise death traps. (In Transparency International. Global Corruption Report. Berlin: Pluto Press. p. 26-27. Available at: http://www. transparency.org/publications/gcr/gcr_2005\#download)

BAKER, R., CHRISTENSEN, J. \& SHAXSON, N. 2008. Catching up with corruption. The American Interest Online, 4(1), Sept.-Oct. Available at: http://www.the-american-interest.com/articlebd.cfm?piece=466 Date of access: 29 Nov. 2010. 
BERNSTEIN, H. 1976. Underdevelopment and development: the Third World today. London: Penguin Books. 376 p.

BRANIGAN, T. 2008. Pupils saved after one school stands firm in quake. The Guardian: 21 May. Available at: http://www.guardian.co.uk/world/2008/may/21/chinaearthquake.china Date of access: 29 Nov. 2010,

DONNELLY, L. 2010. Rot runs deep in police stations. Mail \& Guardian: 10-16 Sept.

DORLING, D. 2010. Injustice: Why social inequality persists. Bristol: Policy Press. 400 p.

ELLICK, A.B. 2010. Floods could have lasting impact for Pakistan. The New York Times: 16 Aug.

FURTADO, C. 1976. Elements of a theory of underdevelopment - the underdeveloped structures. (In Bernstein, H., ed. Underdevelopment and development: the Third World today. London: Penguin Books.)

GLANZ, J. 2006. Idle contractors add millions to Iraq rebuilding. The New York Times: 25 Oct. Available at : http://www.nytimes.com/2006/10/25/world/middleeast/25reconstruct.html?_r=1 Date of access: 29 Nov. 2010.

GOLDEN, M.A. \& PICCI, L. 2005. Proposal for a new measure of corruption, illustrated with Italian data. Economics \& Politics, 17(1):37-75, Mar.

HEWITT, K. 2007. Preventable disasters: addressing social vulnerability, institutional risk, and civil ethics. Geographisches Rundscahu: international edition, 3(1):43-52.

JEFFERY, S.E. 1982. The creation of vulnerability to natural disaster: case studies from the Dominican Republic. Disasters, 6(1):38-43.

KREIMER, A. ARNOLD, M. \& CARLIN, A., eds. 2003. Building safer cities: the future of disaster risk. Washington, DC.: World Bank Publications. 324 p.

LEWIS, J. 1999. Development in disaster-prone places: studies of vulnerability. London: Practical Action. $224 \mathrm{p}$.

LEWIS, J. 2003. Housing construction in earthquake-prone places: Perspectives, priorities and projections for development. The Australian Journal of Emergency Management, 18:2, May.

LEWIS, J. 2005. Earthquake destruction: corruption on the fault line. (In Transparency International. Global Corruption Report. Berlin: Pluto Press. p. 23-30. Available at: http://www.transparency.org/ publications/gcr/gcr_2005\#download)

LEWIS, J. 2007. Climate and Disaster Reduction. Available: Tiempo Climate Newswatch.

LEWIS, J. 2008a. Corruption and earthquake destruction: observations on events in Turkey, Italy and China. Available at: http://www.radixonline.org/resources/lewis-corruption-and-earthquake-destruction_condensed-refs.doc Date of access: 24 Nov. 2010.

LEWIS, J. 2008b. The worm in the bud: corruption, construction and catastrophe. (In Bosher, L., ed. Hazards and the built environment: attaining built-in resilience. Abingdon: Taylor \& Francis. p. 238-263.)

LEWIS, J. 2010a. Corruption and climate change: adaptation and infrastructure. (Second draft for the Global Corruption Report edited by Rebecca Dobson.)

LEWIS, J. 2010b. Corruption and post-disaster reconstruction: the handbook of natural hazards and disaster risk reduction. London: Routledge. 
LEWIS, J. 2010c. Vulnerability, fear and denial and the social geography of risk. Paper read at the 25th DMISA conference held in Jeffreys Bay on 8 and 9 September.

LEWIS, J. \& KELMAN, I. 2010. Places, people and perpetuity: community capacities in ecologies of catastrophe. ACME: an international e-journal for critical geographies, 9(2):191-220. Available at: http:// www.acme-journal.org/vol9/LewisKelman10.pdf Date of access: 29 Nov. 2010.

OLIVER-SMITH, A. 1986. The martyred city: death and rebirth in the Andes. Albuquerque: University of New Mexico Press. 280 p.

PEI, M. 2007. Corruption threatens China's future. Policy Brief55, October. Available at: http://www. carnegieendowment.org/files/pb55_pei_china_corruption_final.pdf Date of access: 1 May 2010.

POIRIER, A. 2010. Draquila: the film Berlusconi doesn't want you to see. The Guardian: 19 May. Available at: http://www.guardian.co.uk/commentisfree/libertycentral/2010/may/19/draquila-silvioberlusconi-film-cannes Date of access: 29 Nov. 2010.

SALIH, M.A. 2010. Corruption carries high cost, World Bank says. Inter Press Service: Journalism \& Communication for Global Change, 16 March. Available at: http://ipsnews.net/news.asp?idnews=50679 Date of access: 29 Nov. 2010.

SHAH, S. 2010. Pakistan flood response prompts rising anti-government resentment. The Guardian: 13 Aug.

SHAKANTU, W. 2003. Corruption in the construction industry: forms, susceptibility and possible solutions. Paper read at the 1st Postgraduate conference of the CIDB on Construction Industry Development held in Port Elizabeth, South Africa on 12-14 October.

SHAMSIE, K. 2010. Pakistan's floods are not just a natural disaster. The Guardian: 5 Aug.

SMITH, D. 2010. Former crusading police chief jailed for corruption. The Guardian: 5 Aug.

TRANSPARENCY INTERNATIONAL. 2009. Corruption perception index 2009. Available at: http://www.transparency.org/policy_research/surveys_indices/cpi/2009 Date of access: 1 May 2010.

TRANSPARENCY INTERNATIONAL. 2010. What is Transparency International? Available at: http://www.transparancy.org/about_us Date of access: 24 Nov. 2010.

WISNER, B., BLAIKIE, P., CANNON, T. \& DAVIS, I. 2004. At risk: natural hazards, people's vulnerability, and disasters. 2nd ed. London: Routledge. 496 p. 